Wilfrid Laurier University

Scholars Commons @ Laurier

6-1-2003

\title{
The International Political Ecology of Industrial Shrimp Aquaculture and Industrial Plantation Forestry in Southeast Asia
}

Derek Hall

Wilfrid Laurier University, dehall@wlu.ca

Follow this and additional works at: https://scholars.wlu.ca/poli_faculty

\section{Recommended Citation}

Hall, Derek, "The International Political Ecology of Industrial Shrimp Aquaculture and Industrial Plantation Forestry in Southeast Asia" (2003). Political Science Faculty Publications. 8.

https://scholars.wlu.ca/poli_faculty/8

This Article is brought to you for free and open access by the Political Science at Scholars Commons @ Laurier. It has been accepted for inclusion in Political Science Faculty Publications by an authorized administrator of Scholars Commons@Laurier. For more information, please contact scholarscommons@wlu.ca. 
Journal of Southeast Asian Studies, 34 (2), pp 251-264 June 2003. Printed in the United Kingdom.

DOI: S0022463403000249 $\quad$ C 2003 The National University of Singapore

\title{
The International Political Ecology of Industrial Shrimp Aquaculture and Industrial Plantation Forestry in Southeast Asia
}

\author{
Derek Hall
}

\begin{abstract}
This paper compares the trajectories over the last two decades of two export-oriented 'boom crops' in Southeast Asia: industrial shrimp aquaculture and industrial plantation forestry. It focuses on differences in the establishment, operation and politics of these sectors to explain why they have experienced very different kinds of 'booms'.
\end{abstract}

During the 1980s and 1990s, industrial shrimp aquaculture and industrial plantation forestry took their places in the long history of 'boom' natural resource sectors in Southeast Asia. The development of these two sectors has been marked by a number of similarities beyond the timing of their emergence. First, these new crops were tied to growing affluence in Eastern Asia. The Japanese 'bubble economy' of the 1980s and the upward revaluation of the yen led to rapid growth in the market for shrimp, and indeed Japan has come close to monopsony with respect to the production of some countries in the region. During the 1990s, rising incomes in the rest of the region and exports to Europe and the United States helped to keep shrimp aquaculture viable as Japanese consumption stagnated. Industrial plantations of fast-growing tree species suitable for pulping, meanwhile, have been encouraged by rapidly rising demand for high-quality paper and for packaging. Second, the foreign exchange potential of these sectors has meant that regional governments and bi- and multilateral aid organisations have assiduously promoted them. Shrimp farms and tree plantations have become increasingly important to Southeast Asian political economies, and have been taken up as primary examples of the regionalisation and globalisation of natural resource sectors in the region.

More fundamentally, there has been a critical shift in the shrimp and forestry sectors away from a 'hunting-and-gathering' model towards one based on agriculture. Until the 1980s, most internationally-traded shrimp originated in the capture fishery, while the trees harvested in Southeast Asian forestry came largely from more or less 'natural' forests, teak plantations being an important exception. ${ }^{1}$ The origins of these shrimp and

Derek Hall is Assistant Professor in the International Development Studies Programme and the Department of Political Studies, Trent University, Peterborough, Ontario, Canada. Correspondence may be addressed to dhall@trentu.ca. For their suggestions, I would like to thank Keith Barney, Philip McMichael, Megan Thomas, an anonymous reviewer for the Journal of Southeast Asian Studies, and especially the participants in the panel on 'Globalisation/Localisation of Natural Resources' at the International Conference of Asian Scholars II, Berlin, August 2001.

1 See, for instance, Nancy Lee Peluso, Rich forests, poor people: Resource control and resistance in Java 
trees were thus largely independent of the production and trade circuits in which they later became enmeshed. With the rise of aquaculture and tree plantations, however, the supply of living organisms has become decreasingly tied to, for instance, coastal shrimp population dynamics, and increasingly related to human stocking and planting decisions. In Karl Polanyi's terms, shrimp and trees were previously 'fictitious commodities' in that while they were not 'objects produced for sale on the market,' they were subject to market mechanisms as though they had been so produced. Now, however, they have become real commodities: the very existence of these shrimp and trees is a consequence of their having been grown-out or planted for eventual sale. ${ }^{2}$ Shrimp and trees are here part of a broader deepening of the incorporation into capitalist production of inputs that were once harvested from nature. ${ }^{3}$ This process derives from the responses of capitalist firms to ecological scarcity (as the availability of natural stocks drops) and the benefits (homogeneity, control over species selection, and so forth) to be gained from newly available techniques of monocultural farming.

Over the last two decades, then, both the shrimp aquaculture and tree plantation sectors have been characterised by state, corporate and donor agency efforts to transform extensive areas of Southeast Asia into new and intensely managed ecosystems in order to pursue foreign exchange earnings. There have also been key differences between these sectors, however - both in the way they have been organised and in the extent to which reality has measured up to the often breathless plans of the promoters. While this article will outline a number of these differences, among the most important has been the variation in the overall trajectories of the two sectors. Shrimp aquaculture, at both the local and to a lesser degree the national levels, has been characterised by a pattern of sudden booms in production followed by equally spectacular crashes. While tens of thousands of people in Southeast Asia have tried their hands at shrimp farming, the mercurial quality of the sector has meant that their efforts have often collapsed almost immediately. Industrial tree plantations, in contrast, have faced their biggest difficulties in getting off the ground in the first place. Opposition to the sector, which has been most intense in Thailand but has taken place in other parts of the region as well, has imposed a brake on plantation expansion. These two sectors have thus been 'boom crops' in quite different senses. To use the puns beloved of headline writers, the shrimp boom has largely followed a 'prawndike' pattern of dramatic production rises followed by equally devastating crashes, while the difficulties that enthusiastic governments and corporations have faced in trying to promote an industrial tree plantation boom have led some to write the sector off as 'pulp fiction'.

This article will use the similarities and variances between these sectors to explain the different kinds of 'booms' they have experienced, as well as the ways in which they have interacted with surrounding communities and the characteristic political alliances that have formed around them. The discussion has been guided by work done in the now

(Berkeley: University of California Press, 1992) and Raymond Bryant, The political ecology of forestry in Burma, 1824-1994 (London: Hurst \& Company, 1997). 'Capture fisheries' have fish caught in the wild, as opposed to fish farms.

2 Karl Polanyi, The great transformation: The political and economic origins of our time (Boston: Beacon Press, 1957). This is not entirely true of shrimp, as we will see later.

3 Martin O'Connor, 'On the misadventures of capitalist nature', in Is capitalism sustainable? Political economy and the politics of ecology, ed. Martin O'Connor (New York: Guildford Press, 1994), pp. 125-51. 
well-established field of political ecology, which foregrounds the relations between human beings and the natural world, or what Marx called the 'human-nature metabolism.' The specific approach taken here differs from most work in political ecology, however, in not being based on close, detailed fieldwork at one or two locations. Rather, the article takes a comparative perspective, examining both the differences between shrimp aquaculture and plantation forestry and the differences within these sectors across nations (in particular, Indonesia, the Philippines and Thailand) and localities. ${ }^{5}$ The analysis begins by identifying what might be called the 'sectoral environmental particularities' of industrial shrimp aquaculture and plantation forestry that is, the characteristic requirements and problems of the new and heavily managed ecosystems created by these sectors. Rather than arguing for a kind of sectoral determinism, however, the article contends that attention must be paid to the ways these sectoral environmental particularities have interacted with different local and national conditions. The objective is thus largely to identify 'translocal' regularities and variations in these interactions.

The analysis will be divided into four sections. After a brief description of the technical characteristics of each sector, the discussion will examine the establishment of shrimp ponds and tree farms in terms of the range of viable farm sizes, local tenure relations and the methods through which land is acquired. It will then canvass the implications of the operation of shrimp and tree farms for local areas, including the ways they are integrated into local communities and economies, the problems of 'selfdestruction' with which they have to grapple and their biological characteristics. These various processes have influenced the politics of these sectors, including the political alliances in which they are embedded, the way each sector and each commodity is represented, and typical forms of social conflict. Throughout the analysis, the importance of the interaction between the political-ecological characteristics of different sectors and changes in the communities that surround them is highlighted.

\section{The move to an agricultural model}

Although the capture fishery dominated the international trade in shrimp until the 1980s, shrimp aquaculture has been practiced for centuries in some parts of Southeast Asia, notably in Indonesia and the Philippines, where shrimp has been a subsidiary crop in milkfish ponds. ${ }^{6}$ Traditional or 'extensive' aquaculture relies on tidal action for the provision of food and shrimp fry, and requires as inputs mainly the labour involved in impounding low-lying areas along bays and tidal rivers where the shrimp can be grown to market size. Modern Asian shrimp farming, which is based on techniques developed

4 On political ecology, see Third World political ecology, ed. Raymond Bryant and Sinead Bailey (London and New York: Routledge, 1997). 'Human-nature metabolism' is discussed in John Bellamy Foster, Marx's ecology: Materialism and nature (New York: Monthly Review Press, 2000).

5 An increasing amount of comparative work is being done in political ecology; see, for instance, Susan C. Stonich and Peter Vandergeest, 'Violence, environment, and industrial shrimp farming', in Violent environments, ed. Nancy Lee Peluso and Michael Watts (Ithaca, NY: Cornell University Press, 2001), pp. 261-86.

6 Chairul Muluk and Conner Bailey, 'Social and environmental impacts of coastal aquaculture in Indonesia', in Aquacultural development: Social dimensions of an emerging industry, ed. Conner Bailey et al. (Boulder: Westview Press, 1996), pp. 193-209; Michael A. Rice and Arthur Z. DeVera, 'Aquaculture in Dagupan City, Philippines', World Aquaculture, 29, 1 (1998): 18-24. 
in Japan and Taiwan between the 1930s and 1970s and focuses on the species Penaeus monodon (black tiger shrimp), is far more capital- and input-intensive than traditional aquaculture. ${ }^{7}$ Semi-intensive ponds are stocked not by the tides but by trawler-caught postlarval shrimp or by hatcheries. Similarly, pumps replace tides as the source of water exchange, and feeds are artificial. Yields are much higher, ranging from 50 to 5,000 kg per hectare, as against 50 to $500 \mathrm{~kg}$ for extensive farming.

Intensive aquaculture involves even closer management. The system uses small ponds ( 0.1 to $1.5 \mathrm{ha}$ ) and is able to densely stock shrimp through a combination of heavy feed inputs, waste removal and aeration. Yields range from 5,000 to 20,000 kg per hectare. ${ }^{8}$ In both semi-intensive and intensive shrimp aquaculture, large amounts of fresh and salt water (which are mixed together to create the brackish water preferred by the shrimp), agricultural chemicals, feeds and farm machinery are brought together to form an artificial ecosystem that, in Peter Riggs' words, 'no more mimics the mangrove forest or the coastal estuary in which it is situated than would a parking lot."

Industrial tree plantations have mushroomed worldwide for many of the same reasons and through many of the same processes as shrimp farms. Just as overfishing has led to plateauing catches of natural shrimp, deforestation, environmental regulation and protest have reduced access to natural or second-growth trees. Technical advances have also contributed to making plantations more viable. By 1993, 95 per cent of Chile's industrial wood production, 93 per cent of New Zealand's and 60 per cent of Brazil's were derived from plantations. ${ }^{10}$ Southeast Asia's move towards tree plantations has been driven by the same forces but was given extra impetus by the rapid growth of regional markets for paper products in the 1980s and 1990s. Different fast-growing species have been chosen for their suitability for local conditions, with Eucalyptus camaldulensis dominating in Thailand and various Acacia species most popular in Indonesia. Ricardo Carrere and Larry Lohmann have pithily described industrial tree plantations as follows:

[they] are much closer to an industrial agricultural crop than to either a forest as usually understood, a traditionally-managed coppice, or a traditional farm plot. Usually consisting of thousands or even millions of trees of the same species, bred for rapid growth, uniformity and high yield of raw material, and planted in even-aged stands, they require intensive preparation of the soil, fertilisation, regular spacing of trees, seedling selection, intensive weeding using machines or herbicides, use of pesticides, thinning, mechanised harvesting, and in some cases, pruning. ${ }^{11}$

While this article will focus on the environmental particularities of shrimp and tree farming, it is important to note certain biological aspects of each species in order to understand the ways in which these sectors differ. Three differences should be highlighted between shrimp and fast-growing tree species: their respective harvest cycles, how quickly the harvested crop needs to be brought to market, and the potential for

7 Yamauchi Kageki, Sakana to Nihonjin [Fish and the Japanese] (Tokyo: Chikuma Shinsho, 1997).

8 Bob Rosenberry, World shrimp farming 1997 (San Diego: Shrimp News International, 1997), pp. 165-8.

9 Peter Riggs, 'Commodities, certification, and value: A social and environmental perspective on shrimp aquaculture' (Unpublished paper, Tufts University School of Veterinary Medicine, 1998), p. 8.

10 Ricardo Carrere and Larry Lohmann, Pulping the South: Industrial tree plantations and the world paper economy (London: Zed Books, 1996), p. 49; an overview of these developments is in Alexander Mather, 'Global and globalizing trends in wood production', Geography, 80 (1995): 355-66.

11 Carrere and Lohmann, Pulping the South, p. 4. 
selective breeding. The fact that shrimp grow from post-larval to harvestable size in just two to three months has contributed to the often fly-by-night, 'slash-and-burn' characteristics of the industry. It is not necessary to make a long-term investment in shrimp farming in order to make returns that, in the words of the Bangkok Post, 'relative to outlay, can probably be bettered only by dealing in illicit drugs. ${ }^{.2}$ Farmed trees, on the other hand, require at a minimum five and more often seven or eight years to reach harvestable size, and thus require a longer time commitment and the ability to assess risks over a period of more than a decade.

With respect to transportation, the biological characteristics of shrimp are much more exacting than are those of trees. They must be moved from harvest to freezing/processing as quickly as possible - some farms in Indonesia manage this in under 20 minutes - and deteriorate significantly in quality each time they are unfrozen; this feature has tended to keep the farming and processing of shrimp quite close together. Logs and wood chips, however, are not nearly so delicate, a fact that has allowed widely dispersed siting of raw materials and processing. Finally, while tree scientists are making efforts through hybridisation and genetic engineering to develop hardier and fastergrowing trees with better fibre content, shrimp have not in fact been fully domesticated in Asia. The post-larval shrimp that stock Asian ponds are either caught from the ocean (a form of fishing with an extremely high bycatch rate, i.e. the quantity of marine life caught inadvertently when fishing for something else) or grown out in hatcheries from wild broodstock. Because economically important shrimp species like black tiger cannot yet be bred in captivity, breeding and genetic engineering cannot be harnessed to address the problems of shrimp farming, although intense efforts to bring the life cycle of these shrimp under human control are underway in Asia. ${ }^{13}$

\section{Establishment}

One of the most important aspects of the move from hunting-and-gathering to an agricultural model in the shrimp and forestry sectors has been the necessity of gaining secure access to land. The establishment of both shrimp ponds and tree farms has involved significant shifts in land relations across Southeast Asia. These shifts have happened in different ways, depending in part on the ways in which shrimp and trees have moved from being 'fictitious' to 'real' commodities. In particular, land relations have depended upon the size of the farms being established, pre-existing tenure relations in the areas in question and the methods through which land has been acquired.

Shrimp farms are virtually always much smaller than tree plantations. While they can contain a number of individual ponds and vary in size, the dominant tendency in Asia has been towards clusters of small to medium-sized farms ranging from under one to five hectares. Tree plantations have tended to be much larger, generally on the order of hundreds or thousands of hectares. Given the difference in size between shrimp and trees, this disparity is hardly surprising; however, it can only partly be explained by the technical and biological characteristics of shrimp and tree farming. One study has argued that shrimp farming is either scale-neutral or else provides advantages to small-scale farming, and that large-scale corporate contract farming arrangements are not well-

12 'High-risk industry roars better than ever', Bangkok Post, 18 May 1998.

13 Jasper Goss et al., 'Agri-food restructuring and Third World transnationals: Thailand, the CP Group and the global shrimp industry', World Development, 28, 3 (2000): 513-30. 
suited to the sector. The authors state that:

In a highly unstable disease environment, small farmers are better able to micromanage, have a more detailed knowledge of local ecologies, and can take advantage of a trial and error approach. Studies based on data obtained from large numbers of farmers in different parts of [Thailand] consistently show that small owner-operated farms are more efficient than medium and large farms operated by hired workers. ${ }^{14}$

This argument, however, is weakened by the existence of large-scale contractfarming arrangements in Indonesian shrimp aquaculture. Indeed, the study goes on to provide a number of other explanations for the tendency towards small shrimp farms in Thailand that derive more from political economy than they do from the nature of shrimp farming itself. These factors include the cost, availability and pattern of control over land; the dense canal networks that already exist in much of coastal Thailand and reduce the cost of establishing farm infrastructure; and government policies forcing banks to lend to farmers. It is thus not clear that there is any inherent optimal size for a shrimp farm. ${ }^{15}$

The large size of tree plantations, however, is linked much more tightly to the nature of the sector. One reason for this is that while the stocking density in a shrimp pond can vary dramatically, on a tree plantation the range of optimal tree spacings is quite small. Anyone wishing to make a significant investment in tree farming is thus obliged to plant at least a few hundred hectares of land, while shrimp farmers can limit their attentions to a few hectares and still turn a profit. In addition, economies of scale on tree plantations (for instance, in land clearance and pesticide application) clearly point towards the benefits of scale. In Indonesia, it has been estimated that the optimal area for an industrial tree plantation is on the order of 30,000 to 50,000 hectares. ${ }^{16}$ Similarly, in Thailand large-scale plantations have tended to be more profitable than smaller ones, and a Japanese survey team in the Philippines estimated that the 2248 ha available at the former site of Clark Air Force Base would be insufficient for an optimally-sized tree plantation. ${ }^{17}$ In Thailand, the turn to contract farming of eucalyptus and other industrial tree species has clearly been a second-best response of corporations that have been unable to establish large-scale plantations, as will be discussed below. ${ }^{18}$ The tree

14 Peter Vandergeest et al., 'A political ecology of shrimp aquaculture in Thailand', Rural Sociology, 64, 4 (1999): 584-5.

15 Ibid., pp. 585-6. On Indonesia, see Dan Murphy, 'Deeper into the morass', Far Eastern Economic Review, 1 June 2000. A general discussion of shrimp farming is in Derek Hall, 'Explaining the diversity of Southeast Asian shrimp aquaculture', paper presented to the annual meeting of the Rural Sociology Association, Albuquerque, New Mexico, 18 Aug. 2001.

16 From a report by the consulting company Jaakko Poyry cited in Wahana Lingkungan Hidup Indonesia (WALHI) and Yayasan Lembaga Bantuan Hukum Indonesia (YLBHI), Mistaking plantations for Indonesia's tropical forest (Jakarta: WALHI, 1994), p. 27.

17 Moriyama Hiroshi, 'Watashitachi ga tsukau kami o ODA ga sodateru!? Tai nado' [ODA pays for the paper we use!? Thailand, etc.], in Nihonjin no kurashi no tame datta ODA [ODA was in aid of Japanese livelihoods], ed. Fuke Yosuke and Fujibayashi Yasushi (Tokyo: Commons, 1999), pp. 12-43; Kaigai Sangyo Shokurin Senta, Firipin kyowakoku ni okeru shokurin tekichi chosa hokokusho [Report on afforestation in the Philippines] (Tokyo: Kaigai Sangyo Shokurin Senta, 2000), p. 51.

18 Roger Clapp has argued, however, that there is likely to be an increase in contract tree farming in Chile for reasons connected closely to the nature of the sector; Roger Alex Clapp, 'Regions of refuge and the agrarian question: Peasant agriculture and plantation forestry in Chilean Araucanía, World Development, 26, 4 (1998): 585. 
plantation sector thus differs from shrimp aquaculture in that investors in the former always prefer large operations.

Both shrimp aquaculture and industrial tree plantations in Asia have largely been established in areas that did not previously have clearly defined property relations in land. Both sectors have tended towards land such as coastal areas or reserved forests that, while legally claimed by the state, is actually inhabited, in some cases by communities that have existed for centuries. This pattern has meant that the establishment of both shrimp and tree farms has often been predicated on the sometimes violent dispossession of these communities and the effective enclosure and expropriation of their land. Here again, however, there has been variation, particularly in the case of shrimp farming. The Asian shrimp aquaculture boom of the last twenty years has contributed to raising the price of coastal land that was not previously of much economic value. As a result, governments and corporations have developed an interest in land which had previously been left to be managed by local communities and/or was still covered in mangrove forests. Along both coasts of Thailand, for instance, most coastal land was legally the property of the government, a fact that worked to the disadvantage of fishing communities as investors moved in to enclose ponds. Similarly, while along the north and east coasts of Java it was possible for fishpond owners to claim title to land once they had invested a certain minimal level of labour in it, most areas were still marked by unclear tenure relations at the beginning of the shrimp boom. ${ }^{19}$

In both Indonesia and Thailand, however, local people have been very much involved in shrimp aquaculture, a fact that has complicated the politics of enclosure, as will be discussed further below. It should also be noted that in some of the major centres of Asian shrimp farming, such as Negros (in the Philippines), the area just inland of the eastern coast of southern Thailand, and the Chao Phraya River basin, shrimp farming has been established in areas that already had well-institutionalised capitalist land relations.$^{20}$ Land for shrimp ponds in these areas has largely been acquired through either the use of the farmer's own land, purchase, or lease.

In the case of tree plantations, again much of the area targeted for the sector whether forest land, degraded scrub or villages and farmland -has been under the de jure control of the state. In Thailand, for instance, most of the push to establish plantations in the 1980s took place in the government-owned reserve forests, while plantation establishment in Indonesia has largely occurred through government awards of concessions on the outer islands. ${ }^{21}$ The scale of operation favoured by forestry companies has meant that purchasing or leasing sufficiently large chunks of contiguous land from private owners has generally been impossible in Southeast Asia. However, this has not been the case for Japanese companies setting up tree plantations in Australia, and it seems that purchase and lease have been the primary means of establishment of pine

19 Miriam Huitric, 'The Thai shrimp farming industry: Historical development, social drives and environmental impacts' (M.A. thesis [Examensarbete 1998: 13], Stockholm University, 1998); George W Chamberlain, 'Shrimp farming in Indonesia 1: Growing techniques', World Aquaculture, 22, 2 (1991): 14. 20 See Mark Flaherty and Peter Vandergeest, "Low-salt" shrimp aquaculture in Thailand: Goodbye coastline, hello Khon Kaen!', Environmental Management, 22, 6 (1998): 817-30; and Mike Polioudakis, 'Synopsis of results of research on Southern Thai shrimp farming: Some recommendations' (unpublished paper, 2000).

21 WALHI and YLBHI, Mistaking plantations. 
plantations in the Araucanía region of Chile.22

In practice, of course, these concessions on nominally state-owned land in Southeast Asia come into conflict with the claims of the inhabitants. In Indonesia, this conflict has mostly been with communities practicing swidden agriculture, in part because many companies in Indonesia have sought plantation concessions in forested areas primarily in order to cut and sell the standing timber. ${ }^{23}$ In Thailand, conflict was with denser and more settled communities which were producing export crops for the world market and which had in some cases been encouraged by the state to settle in the reserve forests in the 1960s and 1970s as part of the war against the Communist Party of Thailand. Given the common pattern of eviction, and the close involvement of the military with tree plantations, it is not surprising that Tasaka Toshio has modified Marx's description of enclosure in England to say that in Thailand 'trees eat people. ${ }^{24}$ It should be noted, however, that in some cases the move to farming of trees has actually facilitated the ability of peasants to claim more secure land tenure. Peasants engaged in contract tree farming in Thailand have been able to use the presence of trees on their land as an argument for being granted better tenure certificates, and indeed the role of trees in asserting land claims has been identified in many parts of the world. ${ }^{25}$

\section{Operation}

The above section has outlined the similarities and differences in the establishment of shrimp farming and tree plantations. This section will briefly discuss the characteristic patterns in the ways that these two sectors interact with the political economies and ecologies around them once they are up and running. One striking difference is the extent to which shrimp farming and tree plantations are integrated into local political economies. As noted above, shrimp farms in Asia have generally been quite small, and while participation by urban and corporate capital has certainly been significant, the major farming centres have mostly seen a mix of absentee and local ownership. Local participation in the sector, whether through ownership or employment, has thus tended to be fairly high. Industrial tree plantations have displayed the opposite pattern. These projects have almost all been owned by large corporations and staffed by workers brought in from outside; in addition, tree plantations have (as already mentioned) tended to displace pre-existing land uses on a wide scale. Local ownership has been close to non-existent and local employment relatively insignificant in comparison to the opportunities destroyed by plantations. ${ }^{26}$ There have, of course, been exceptions to both

22 Hisada Mutsuaki, 'Wagakuni minkan kigyo no kaigai sangyo shokurin no doko' [Trends in our country's private overseas industrial tree planting], Kokusai Noringyo Kyoryoku [International agriculture and forestry cooperation], 22, 8 (2000): 18-28; Clapp, 'Regions of refuge'.

23 Lesley Potter and Justin Lee, Tree planting in Indonesia: Trends, impacts and directions (Bogor, Indonesia: Center for International Forestry Research, 1998), p. 16.

24 Tasaka Toshio, Yukari bijinesu: Tai shinrin hakai to Nihon [Eucalyptus business: Japan and forest destruction in Thailand] (Tokyo: Shin Nihon Shuppansha, 1992). On dispossession in Indonesia see Potter and Lee, 'Tree planting in Indonesia', p. 45.

25 Pearmsak Makarabhirom, 'A study on contract tree farming in Thailand' (Ph.D. diss., Tsukuba University, 1998); Richard A. Schroeder, 'Shady practice: Gender and the political ecology of resource stabilization in Gambian garden/orchards', Economic Geography, 69, 4 (1993): 349-65.

26 Potter and Lee, Tree planting in Indonesia, report that 'villagers seem to view a rubberwood estate more favourably than a pulp or timber plantation because of the opportunity to work felling the trees before they are ready for felling' (p. 18); industrial tree plantations are discussed on pp. 36, 39. 
of these broad patterns. Indonesian transmigration projects have staffed shrimp farms of hundreds or thousands of hectares with transmigrants from Java with little integration into local economies. Conversely, contract tree farming in Thailand has seen both smaller farms and more participation from local people than have large-scale plantations. For the most part, however, shrimp farms have been much more closely integrated into local communities than have tree plantations.

Just as shrimp farms and tree plantations have brought socio-economic changes to local communities, so environmental change has also been central to the fate of the two sectors. The most remarked-upon aspect of the problems that shrimp farming causes for local people has been the destruction of mangrove forests. Shrimp aquaculture demands that existing ecosystems be obliterated to make way for ponds, which has often meant the destruction of mangroves. These forests, which grow along tropical coasts and brackish waterways, provide a number of vital ecological services, including preventing coastal erosion and storm damage, filtering upstream pollutants before they enter the ocean (and thus protecting other ecosystems), serving as a breeding and feeding ground for countless fish species, and cycling and storing nutrients. Mangroves are under intense pressure throughout tropical Asia and the ecosystemic services they provide may soon be permanently lost. The role of shrimp aquaculture in mangrove destruction, however, is unclear. Activists, scholars and governments have all claimed that shrimp farming is the primary cause of mangrove destruction in many Asian countries, while industry sources have rejected these claims. Whatever the damage done in the past, the industry is now moving away from mangrove zones because of controversy and tighter regulation, and because mangrove soil chemistry is 'sub-optimal' for semi-intensive production and 'unsuitable' for intensive production. ${ }^{27}$ To the extent that shrimp farms have been responsible for mangrove loss, however, they have contributed through the destruction of habitat and breeding grounds to the decline of coastal fisheries on which local people had previously relied for much of their income and food. ${ }^{28}$

Shrimp farming has also caused significant problems for local communities, and for agriculture in particular, through its thirst for water. Excessive exploitation of groundwater has led to the drawing down of local aquifers and in some cases to salinisation (as seawater moves in to take up the space previously occupied by underground fresh water). In some of the worst affected regions there has been extensive ground subsidence, with buildings in Taiwan sinking a storey or more. Farmers who have leased land to shrimp farms have also objected to the salt deposits left behind in their fields, rendering them unsuitable for agriculture..$^{29}$ Another issue related to water usage has been the dumping of shrimp farm effluent into communal waterways, which degrades the water available for local agriculture.

Similarly, tree farms have continued to cause problems for their neighbours even after they have been established, for two major reasons. First, compared to mixed forests

27 Bob Rosenberry, World shrimp farming 1996 (San Diego: Shrimp News International, 1996), p. 166; Imre Csavas, 'Important factors in the success of shrimp farming', World Aquaculture, 25, 1 (1994): 43. See also Piamsak Menasveta, 'Mangrove destruction and shrimp aquaculture', World Aquaculture, 28, 4 (1997): $36-42$.

28 Huitric, 'Thai shrimp farming industry'.

29 On groundwater see, for instance, 'Prawn farms threaten Mindanao's water supply', (Manila) Sunday Chronicle, 22 Aug. 1993, and Philip Liu, 'Water supply in peril', Free China Review, August 1993. Salt deposits are mentioned in Flaherty and Vandergeest, "Low-salt" shrimp aquaculture', p. 827. 
tree plantations have quite different ratios of (a) water intercepted by foliage to that reaching the ground, (b) runoff to water infiltrating the soil, and (c) evapotranspiration to water reaching the subsoil. ${ }^{30}$ Eucalypts, in addition, absorb water from further underground than do other trees and plants. Plantations thus destabilise water cycles, with results including reduced water flow throughout the year, the disappearance of streams during the dry season, and damage to other ecosystems facing reduced access to water. Farming, irrigation, livestock and fishing in areas around plantations all suffer. A second reason is that even when locals are not evicted from their land, monocultures of eucalyptus afford none of the ecological benefits which mixed forests provided to people living nearby - for instance, grazing land, fodder and firewood, and intercropping. ${ }^{31}$

With respect to the long-term viability of these sectors, it must be noted that while environmental sources of conflict with local communities have been important in both cases, shrimp farming confronts intense difficulties even in the absence of such conflict. While shrimp aquaculture has been criticised for the damage it does to mangroves, the environmental issues which most concern the industry are those which make shrimp farming prone to undermining its own conditions of existence. Modern shrimp aquaculture has faced four major environmental problems that have made the sector prone to sudden crashes in production levels and long-term malaise. ${ }^{32}$ First, shrimp are highly sensitive organisms, and as such are particularly vulnerable to upstream pollution (for instance, industrial effluent or agricultural runoff) entering their water supply. Second, shrimp ponds themselves produce sizable amounts of effluent; and when water intake and outflow systems in areas crowded with farms are not well-designed, there is a strong tendency for farms to pollute each other's water supply. Third, the industry uses fresh water in sufficiently large quantities that it has often depleted local supplies.

A final issue is that dense monocultural stocking of shrimp in conjunction with intraregional flows of broodstock and the transfer of water from farm to farm have left industrially-farmed shrimp highly susceptible to disease outbreaks. No country in Asia has been immune to these, and the industry has devoted hundreds of millions of dollars to efforts to control them. The disease-induced crash that hit Ecuador in 2000, which is estimated to have cost the country $\$ 1$ billion in export revenues and half a million jobs, is only the most recent of the spectacular declines in production that have plagued shrimp aquaculture..$^{33}$ In these four ways, participants in industrial aquaculture are forced to confront some of the environmental consequences of their production choices in the form of declining profits or even bankruptcy. Tree farm monocultures, on the other hand, while also faced with disease problems, have generally not been overwhelmed by them.

\section{Politics and representation}

The above sections have discussed the ways in which the particularities of the capitalisation of nature in shrimp aquaculture and tree farming have shaped the

30 Carrere and Lohmann, Pulping the South, pp. 64-5.

31 See also 'Eucalyptus a bad experience for farmers: Harms nearby crops, kills water sources', Bangkok Post, 6 Sep. 1999.

32 Tania Li describes a similar boom pattern in the cocoa sector in her 'Local histories, global markets: Cocoa and class in upland Sulawesi', Development and Change, 33, 3 (2002): 419.

33 'Ecuador: State of emergency declared over lost shrimp revenue',

http://www.shrimpaction.com/News/Ecuador5.html 
organisation of each of these sectors and their interaction with the political economies and ecologies that surround them. The patterns identified above have in turn affected the ways these sectors have been represented ideologically, the types of political alliances that have formed around them and the forms of conflict that have attended these farms. An analysis of the politics of these sectors highlights first, the critical influence that contention has had on their respective trajectories and second, a fascinating disjuncture between the degrees of opposition they have provoked at the domestic and international levels.

Shrimp have long been associated with wealth and longevity in many parts of Asia; in Japan, for instance, the idea that shrimp look like venerable old men has made them a staple of New Year's parties. That shrimp have been something of a luxury good underlined this image. In Southeast Asia during the late 1980s and early 1990s, the incredible amounts of money that could be made from shrimp farming transformed the sector into a symbol of economic boom times. In particular, the possibility of people from the middle class or even below hitting the jackpot with a couple of hectares of shrimp ponds meant that shrimp became associated with getting rich quick. Proponents of shrimp farming have thus been able to draw on both the association of the shrimp itself with luxury and longevity and on the proliferation of Horatio Alger success stories associated with the sector.

The regional pulp and paper industry, meanwhile, has made much of the comparatively low rates of per capita paper consumption in Southeast Asia in arguing that tree plantations are essential for bringing the benefits of modernity and information economies to the region. However, the lack of positive associations with eucalyptus and the dearth of cases of poorer people doing well out of tree farming has meant that there is much more space for negative representations of tree plantations. In Thailand, eucalyptus has been perceived by farmers as a 'selfish tree' or a 'tree of hell.' One of Amare Tegbaru's informants in Thailand made explicit the connection between the qualities of eucalyptus and the infringement by the state onto local lands, arguing that 'eucalyptus is like the state. It sucks and takes everything for itself. It competes with other plants and trees, and grows by undermining everything around it. The same is true of the state. It has become rich and powerful while we remain weak and poor. ${ }^{34}$

The stronger negative connotation associated with tree plantations has manifested itself in the local - though not the global - NGO politics of the respective sectors. Local NGOs in Indonesia, the Philippines and Thailand, while generally critical of industrial aquaculture, have tended not to become involved in active resistance, likely because of the sector's complicated politics and the divisions it brings about in local communities. It is notable in this context that the most intense conflict over shrimp farming in Thailand - the seesawing fight over the banning of low-salinity aquaculture in inland rice farming areas - has been primarily a battle between shrimp and rice farmers and their respective political patrons. ${ }^{35}$ Perhaps the main example of NGO involvement in Asian shrimp politics has been the work of human rights groups in Indonesia to support calls

34 Amare Tegbaru, 'Forests, farmers and the state: Environment and resistance in Northeastern Thailand' (Ph.D. diss., Stockholm University, dist. Almqvist \& Wiksell International, 1998), pp. 160-1.

35 'A change of heart', Bangkok Post, 23 July 1998; 'Govt walks minefield in shrimp-paddy battle', The Nation, 22 Dec. 1998. On NGO involvement see Flaherty and Vandergeest, "Low-salt" shrimp aquaculture' and Li, 'Local histories', p. 430. 
for better working conditions by workers at the giant shrimp estates in southern Sumatra, but this battle has had more to do with labour relations than with shrimp farming per se. With respect to tree plantations, however, local NGOs have had no such reservations, and have engaged wholeheartedly in struggles in Thailand and Indonesia. As noted above, tree plantations in Asia have often been established through the militarised dispossession of local people who are subsequently unable to find employment on the new plantation and derive few to no benefits from it. While states in the region have attempted to mobilise images of reforestation and paper consumption as symbols of development, in practice the sharp distinction between elite benefit and local impoverishment associated with tree plantations has motivated NGO opposition. ${ }^{36}$

Internationally, interestingly enough, the situation has been reversed, with shrimp farming attracting more opposition than plantation forestry. Industrial shrimp farming has seen the organisation of international opposition movements and boycott campaigns that have responded mainly to the destruction of mangrove forests. ${ }^{37}$ Globally, shrimp's image as a luxury product has worked to encourage opposition to industrial aquaculture, given the perception of developed-world luxury consumption ravaging coastal Asian environments. The issues that have been most prominent in Western and local NGO critiques of shrimp farming have been quite different, however. In a response to environmentalist critiques of shrimp farming, the Shrimp Council (an industry organisation) has focused almost entirely on issues such as mangroves, turtle excluder devices, and bycatch in the trawling of shrimp larvae - the main concerns of Western groups - rather than addressing local concerns such as access to land, water pollution, salinisation, ground subsidence and violence. ${ }^{38}$ International opposition to industrial plantation forestry has been slower to develop, likely because the association with reforestation initially increased the appeal of the sector for some Western environmental groups. However, concern about industrial plantations has been growing in recent years, stimulated by the anti-plantation campaign of the World Rainforest Movement and by the sudden rise to prominence of the sector as a possible source of carbon sinks under the Kyoto Protocol..$^{39}$

While a good deal of conflict has certainly surrounded shrimp aquaculture in Asia, it is perhaps surprising that there has not been more, given the damage that the industry has done to fishing and farming in the areas that surround it,. The industry has seen much more contention and violence in other countries, including Honduras and India. ${ }^{40}$ While the range of factors that work together to explain the eruption or otherwise of social conflict is obviously very large, a comparison with the industrial tree plantation sector suggests some possible explanations for the difference. In particular, the

36 Larry Lohmann, "Visitors to the commons: Approaching Thailand's "environmental" struggles from a Western standpoint', in Ecological resistance movements: The global emergence of radical and popular environmentalism, ed. Bron Raymond Taylor (Albany: SUNY Press, 1995), pp. 109-26; WALHI and YLBHI, Mistaking plantations; and Tasaka, Yukari bijinesu. There are NGOs in the region that support tree plantations; see 'Philippines tree-growers, others oppose total log ban', Asia Pulse, 1 Dec. 1999.

37 Susan C. Stonich and Conner Bailey, 'Resisting the blue revolution: Contending coalitions surrounding industrial shrimp farming, Human Organization, 59, 1 (2000): 23-36.

38 Rosenberry, World shrimp farming 1996, p. 146.

39 World Rainforest Movement, Climate change convention: Sinks that stink (Montevideo, Uruguay: World Rainforest Movement, 2000).

40 Stonich and Vandergeest, 'Violence'. 
comparatively small size of individual shrimp farms, the integration of local people (particularly elites) and the potential for windfall profits associated with the sector have meant that united opposition to the sector at the community level in Indonesia, the Philippines and Thailand has been fairly rare. Indeed, what protest has occurred often seems to have been against absentee owners. ${ }^{41}$ Local-level opposition thus appears to have been restricted for the same reasons that local NGOs have found it difficult to get involved in conflicts over shrimp farming.

Tree plantations, which like shrimp farms have been associated with dispossession and damage to local agriculture, have differed on most of these points. They are very large, poorly integrated into local communities, and provide little opportunity for local elites beyond the prospect of being bought off by corporate or state actors. ${ }^{42}$ Furthermore, while the land for both sectors has been acquired in a variety of ways in Asia, tree plantations have seen a more consistent pattern of de facto enclosure, often with military participation. These conditions have united communities against tree plantations and made it easy to demonise the sector and the trees themselves, as noted above. Thus, Tasaka argues that the wave of peasant resistance to plantations that swept the Northeast of Thailand in the mid-1980s was triggered by a highly militarised attempt by the Thai government and corporate actors to relocate peasants living in the reserve forests. ${ }^{43}$ The militarisation of forest policy can be seen most clearly in the Khor Jor Kor resettlement project, initiated under military rule in March 1991 and described as one of the military's 'most ambitious money-making programs."44 The project, which was cancelled in June 1992 after Thailand's return to democracy, sought to resettle 250,000 families from reserve forests between 1991-6 and to sell the newly-vacated land for eucalyptus plantations. Intense resistance to these projects has more or less brought the industry to a standstill in Thailand, where frustrated pulp and paper companies have turned to contract farming of eucalyptus as a second-best alternative now that it is clear that large areas of land for plantations will not be forthcoming. ${ }^{45}$ In Indonesia, the Finnantara company, which has attempted to defuse resistance to plantations by taking a more conciliatory approach to local concerns, is instead being abandoned by investors and government officials frustrated with the time required to run 'kinder, gentler' industrial tree plantations. ${ }^{46}$

\section{Conclusions}

This article has moved from the more local and technical to the more political and larger-scale in explaining the differing success of industrial shrimp farming and industrial tree plantations in Southeast Asia. The organisation of these sectors, the way they interact with the political ecologies around them, and the politics and contention that they have inspired are, it is argued, rooted in good part in the particularities of the ways in which they have moved away from hunting-and-gathering techniques towards methods which are more agricultural. As peripatetic sectors have become sedentary, the

41 Flaherty and Vandergeest, "'Low-salt" shrimp aquaculture', p. 827.

42 On this last point see Potter and Lee, 'Tree planting in Indonesia.'

43 Tasaka, Yukari bijinesu, p. 171.

44 Stan Sesser, 'The course of corruption', Mother Jones, 93 (1993): 67.

45 Permsak, 'Study on contract tree farming in Thailand'.

46 Potter and Lee, 'Tree planting in Indonesia', pp. 16-9. 
control over land required in order to establish production has meant that these sectors have been associated with enclosure and dispossession, and the day-to-day operations have caused significant environmental problems for local farming and fishing. However, the ways in which these broad similarities have translated into oppositional politics in shrimp and tree farming have varied, in part because of such factors as economies of scale and integration into local communities.

While the politics of shrimp farming in Southeast Asia have been complex and important, they have not ultimately posed a major threat to the sector's perpetuation in the region. Only in the Chao Phraya basin in Thailand has a ban been imposed on shrimp farming (as was done in India) because of the damage that it does to local communities, and even that ban may well be revoked. ${ }^{47}$ The primary threat to shrimp aquaculture in the region has been not protest but the sector itself, as water pollution, salinisation and particularly disease epidemics have wiped out billions of dollars worth of production in massive crashes. Industrial tree plantations have also been susceptible to disease, but their spread in Southeast Asia has primarily been slowed by opposition from people who have been dispossessed by their establishment or whose livelihoods are threatened by their very existence. Interestingly, while Japanese corporations have been scouring the world for the last 15 years looking for locations for industrial tree plantations and have invested heavily in the sector in Australia, their initial interest in Southeast Asia quickly dissipated when they came to understand the politics of tree plantations in the region. ${ }^{48}$ At present, there is only one Japanese tree plantation in Southeast Asia - in Vietnam. While this article has not been able to address all of the relevant factors - variations in state support, for instance, have been critical in both cases - it has emphasised that the confluence of sectoral particularities, community responses and political alliances has been central in shaping the 'prawndike' and 'pulp fiction' trajectories of these two sectors.

47 'Government to relax shrimp farming restrictions', (Bangkok) Business Day, 18 July 2001; 'Shrimp ban remains for now', Bangkok Post, 1 Aug. 2001.

48 Morimoto Taiji, 'Parupu-zai no shorai tenbo' [Future direction of pulp materials], Kami-pa Gikyoshi [Paper-pulp technical cooperation], 47, 1 (1993): 45; and Derek Hall, 'Environmental change, protest, and havens of environmental degradation: Evidence from Japan-Southeast Asia relations', Global Environmental Politics, 2, 2 (2002): 20-8. 